\author{
Andrzej Sztando \\ Wrocław University of Economics \\ e-mail: andrzej.sztando@ue.wroc.pl \\ ORCID: 0000-0002-6204-9884
}

\title{
CONTEMPORARY EXPECTATIONS \\ OF POLISH SMALL TOWN AUTHORITIES TOWARDS THE STATE POLICY OF LOCAL DEVELOPMENT
}

WSPÓLCZESNEOCZEKIWANIAWLADZLOKALNYCH
MALYCH MIAST WOBEC PAŃSTWOWEJ POLITYKI
ROZWOJU LOKALNEGO

DOI: $10.15611 / \mathrm{pn} .2019 .5 .15$

JEL Classification: H7, O2, R5

\begin{abstract}
Summary: The article is devoted to the issue of stimulating local development (LD). Its purpose is to present contemporary expectations of small town authorities towards the Polish state's local development policy. The introductory part is devoted to the key categories: LD and local development policy. The desirable features of the state's local development policy were also discussed. The identified expectations were divided into main groups: stopping activities interpreted as limiting territorial self-governance, changing the distribution of aid funds, the multidimensional reform of the self-government finance system, as well as improving the municipal instruments to stimulate LD. Within each group, specific expectations identified were discussed. An additional group of other expectations, characterized by a high level of diversity, was also distinguished and discussed. The research was carried out using a diagnostic survey method with the standardized long personal interview technique in 2019.
\end{abstract}

Keywords: local development, public governance, state policy of local development, self-government, Poland.

Streszczenie: Artykuł dotyczy problematyki stymulowania rozwoju lokalnego (RL). Jego celem była prezentacja wyników badań współczesnych oczekiwań władz małych miast wobec polskiej państwowej polityki rozwoju lokalnego. Wstępną część artykułu poświęcono kategoriom dla niego kluczowym, tj. RL i polityce rozwoju lokalnego. Omówiono też pożądane cechy państwowej polityki rozwoju lokalnego. Zidentyfikowane oczekiwania podzielono na grupy główne, takie jak: zatrzymanie działań interpretowanych jako ograniczanie samorządności terytorialnej, zmiany systemów dystrybucji środków pomocowych, wielowymiarowa reforma systemu finansów samorządowych, a także udoskonalenie gminnego instrumentarium stymulowania RL. Wyróżniono także i omówiono dodatkową grupę oczekiwań pozo- 
stałych, charakteryzujących się wysokim zróżnicowaniem. Badania przeprowadzono metodą sondażu diagnostycznego z wykorzystaniem techniki zestandaryzowanego długiego wywiadu osobistego.

Słowa kluczowe: rozwój lokalny, zarządzanie publiczne, państwowa polityka rozwoju lokalnego, samorząd terytorialny, Polska.

\section{Local development in a local and supralocal perspective}

The category of local development (LD) should be seen in two ways at the same time. The first way can be described as local. It consists in understanding it as a long-term, non-unified, multidimensional, self-sustaining process of transforming the structures of the local system and the connections between them and their connections with the environment, co-forming desirable supralocal processes, created in a planned, participative, coordinated manner and in accordance with the idea of integrated order, above all through and in the interest of the local community, through consensus-based mobilization of mainly endogenous factors. To simplify, the local system is commonly identified with the commune, and therefore LD in the local perspective can be equated with the development of the commune. The goal of LD perceived in such a way is to increase the quality of life of the local community by satisfying its needs, but at the same time generating useful values for the supralocal environment. Most scientific approaches to LD express this kind of its perception, e.g. (Garofoli, 2009, p. 225; Marques, 2011, p. 144; Pietrzyk, 1995, pp. 89-90; Wojtasiewicz, 1990, p. 38).

The second way of understanding LD is supralocal. Such perception means its conceptualization and identification on the scale of supralocal systems, i.e. regions, states, associations of states (e.g. the EU), and even on a global scale. In the supralocal perspective, it is perceived as such transformations of the structures of the above supralocal systems and relationships between these structures and their environment, which are largely the result of LD processes taking place in the local systems that make up them. However, it is not only about the processes of development of many local systems and their effects combined into supralocal, simple "sums". The main thing is that thanks to the network interactions taking place between local systems, as well as between them and other supralocal entities (e.g. states, companies, organizations), existing and new, supralocal - thus regional, state and global - development processes are stimulated, protected and intensified. Generalizing and simplifying LD in a supralocal perspective means the transformation of LD processes into supralocal development processes. The purpose of LD understood in this way is to increase the quality of life of regional and state societies as well as otherwise delimited, supralocal human communities. In this approach, LD is therefore also treated as one of the most important, modern ideas for the development of the modern state and its regions, as well as international communities. It is also treated as a partial alternative to the unified development model created by large businesses operating in the liberal conditions of an imperfect market. 
Partial, because based on a consensus on the need to combine supralocal concepts of LD with the concepts and processes of spatial concentration of capital, corporate development, unification, the international division of labour, globalization, etc. LD in a supra-local perspective is therefore also seen as an object of supralocal authorities' activities, creating conditions for LD processes and their transformation into supralocal development processes. A supralocal way of perceiving LD, although it also appears less often in the literature (Rezsohazy, 1988, p. 17; Pietrzyk, 1995, pp. 89-90). Local and supralocal categories of LD, together form a paradigm of LD based on contemporary localism, complementary to the paradigm of regional development and incorporated by the paradigm of territorial development.

\section{Local development policies in a local and supralocal scale}

The practical use of the LD paradigm in individual countries, regions and local systems is varied. Nevertheless, due to its creative potential and popularization of localism, its application is spreading on a global scale. The entities with the greatest capabilities in this regard are public authorities at various levels. They can therefore conduct a policy, in the formal-legal, behavioural, post-behavioural, functional and rational understanding (cf. Leksykon 2004, pp. 329-330), consisting in striving to realize LD, which can be called a local development policy. Depending on the territory of the action appropriate for the authority, this policy has different substantive content. Therefore we can distinguish the local development policy pursued by local authorities, which can be called the local policy of local development and local development policies pursued by supralocal authorities, which can be referred to as supralocal policies of local development. This division is consistent with the concept of perceiving LD from local and supralocal perspectives.

The concept of a local development policy pursued by local authorities appears rarely in the literature (e.g. Ofiarska, and Ofiarski 2008, p. 68; Pająk, 2007, pp. 75-77). It can be described as the adoption and permanent acceptance by these authorities of the LD paradigm, expressed by the desire to achieve LD in a local perspective and partly in a supralocal perspective. Among the objectives of the local policy of local development, therefore, the goal of LD perceived from a local perspective (quality of life of the local community) dominates, and it is complemented by the goal of LD seen from a supralocal perspective (quality of life of supralocal communities).

The concept of a local development policy pursued by supralocal authorities has not yet been defined. It can be described as the adoption and permanent acceptance by these authorities of the LD paradigm expressed by striving for LD processes to support and co-create supralocal development processes and transform into them, as well as striving to ensure LD processes in local systems (communes) included in a given, supralocal. The goals of this policy therefore consist of the goal of LD seen from a supralocal perspective and the goal of LD seen from a local perspective. In the case of the latter, however, it is mainly about the development of all local systems 
that are parts of a given, supra-local - and sometimes only one of them or a certain group of them - e.g. those experiencing a serious crisis.

Considering the individual scenes on which these policies can be conducted and their creators, we can distinguish:

- the subregional policy of local development conducted by subregional authorities, in the Polish case, by authorities of a county ['powiat'];

- the regional policy of local development pursued by the regional government, in the Polish case, of the voivodeship;

- the state policy of local development conducted by the state authorities;

- the international policy of local development conducted by the authorities of international organizations such as the EU, the UN and the World Bank, but also by some of the richest countries such as the USA.

\section{State policy of local development}

The supralocal policy of LD with the greatest creative potential is usually the state policy of local development. The state authorities running it usually have the richest instruments in this field and the strongest mandate to create and use it. This policy also has the richest literature reflection, especially in countries where it has the longest traditions, such as Italy (cf. e.g. Governa, Salone, 2004). Within the framework of this policy, the basic way of pursuing the dissemination of LD processes is to provide these processes with conditions for their appearance and course. These are following conditions:

- political, e.g. democracy, freedom of speech, decentralization of power by building a system of local government units with bottom-up elected and evaluated authorities with protected autonomy; pluralism and respect for minority rights, protection of subjective rights;

- organizational, e.g. decentralization of public tasks and methods of their performance; determining which of the decentralized tasks are compulsory; spatially appropriate organization of the state special administration, principles of cooperation between public entities;

- legal, e.g. defining the boundaries of social, economic and environmental activities; shaping pro-entrepreneurial conditions for economic and social activity; ensuring consistency of the law regulating the functioning of authorities at various levels;

- financial, e.g. decentralization of public finance and their organization; construction and regulation of capital markets; creation of financial support for pro-development projects; supporting creators of pro-development projects in obtaining financing sources; supervising the public finance;

- infrastructural e.g. construction and maintenance of supralocal technical and social infrastructure, ensuring common access to it; 
- informational, e.g. collecting, processing and providing access to information necessary to conduct local policy of local development; dispersion of innovative and traditional patterns of development;

- educational, e.g. dissemination of knowledge about the contemporary paradigm of LD; organization of professional education systems for local government staff; organization of public education systems.

Therefore, these are both the conditions for the initiation and the conduct of LD processes occurring with and without the participation of local authorities.

However, state's efforts to ensure LD do not rely solely on creating conditions for LD. They also include initiating and dynamizing LD processes where they do not occur or where their dynamics are unacceptably low. In particular, where LD can quickly meet the basic, most pressing needs, such as in the poorest parts of the world, in monofunctional cities affected by a structural crisis or in post-totalitarian, or postconflict regions. Aid programs targeted at local beneficiaries, e.g. local governments, entrepreneurs and NGOs, are typical in this respect. Point allocation of technical and social infrastructure, pro-development public institutions and investment capital is also typical.

State policy of local development also means inspiring, supporting and promoting local policies of local development. This consists in encouraging local authorities to conduct a local development policy, making them aware of the legitimacy of such behaviour, as well as seeking and propagating examples worth following. There is also training for local authorities and administration as well as other forms of education aimed at disseminating knowledge on LD and the methods of its creation. Under the condition of demonstrating the positive and strong effects in terms of $\mathrm{LD}$, local government projects are also co-financed from state funds. Therefore this activity is similar to the one described above, initiating and dynamizing LD processes by state authorities. The difference is that in this case, local authorities make a subjective decision about the type of development-oriented activities and implement them themselves.

State actions disseminating LD also involve the creation of regional and subregional local development policies. These activities consist primarily in ensuring the existence and conditions for the effectiveness and efficiency of these policies (cf. Malik, 2012). For example, legal solutions constituting regional and subregional authorities and their competences, creating regional and subregional instruments for stimulating LD, enabling cooperation with local authorities and even obliging them to it. Financial solutions which determine the driving force of these policies, are also of great importance. Similarly to local policies of local development, the state's creation of regional and subregional local development policies also takes the form of inspiring, supporting and promoting them. The most measurable forms of such support are e.g. transfers of state money to regional and subregional budgets for the implementation of projects stimulating LD. 
As indicated, supralocal policies of local development, in addition to providing LD processes in local systems, include efforts to ensure that LD processes support, co-create and translate into supralocal development processes. State policy of local development in this respect consists primarily in constructing a network of flows of concepts, information, capital and people, creating points for their creative confrontation and creating some interlocal markets, e.g. markets of financing and the commercialization of innovation. Therefore, state authorities play the role of catalysts for these processes and creators of synergistic and multiplier mechanisms multiplying and transforming the effects of LD created in many local systems. This part of the presented policy is the most difficult to conduct, and practical experience in this field is new and in many countries, including Poland, it is the subject of ongoing experiments, assessments and debates (see Rogers, 2006). Among them are: innovation exchanges and banks, databases of public administration reference procedures, institutionalized public debate forums, interlocal rules for co-creation of supralocal policies, mechanisms of domains horizontal financing, industrial and technological clusters, social economy clusters and other networks of not only economic cooperation.

The state's local development policy is not only about one-way interactions originating at state level, but the final outcome at local level. It also involves obtaining information on LD processes and local expectations in this regard. This is done as part of official statistics, the activities of local government organizations and joint "state-government-and-self-government" bodies, as well as within the framework of scientific research. These activities are a feedback loop of the discussed policy, conditioning both its effectiveness and efficiency, as well as its adequacy to the expectations of local authorities.

\section{Objectives, objects, method and course of research}

Taking into account the importance of the feedback loop presented above, the author decided to carry out research aimed at identifying the basic expectations of a selected group of local authorities towards contemporary Polish state policy of local development. From among the available options, the local authorities of small towns were chosen as they constitute a special category of settlement units. The high number of such localities, their supra-local functions, combined socioeconomic potential and even spatial distribution mean that their importance in the development of the country is high. Many of them play the role of LD centres, fulfilling traditional, supply, service and commercial functions in rural agricultural space, as well as new functions in rural industrial, forestry or service spaces. Some of them perform functions of a wider territorial range. This applies to, for example, towns with sanatory (healthcare), tourism and recreation, logistics, port, fuel and energy, mining and production functions. For the rural surroundings, small towns are relays of values, the roots of which most often arise from large cities. They are 
also places of concentration of administrative, educational, medical, information, social and other services. They are also locations of nodal technical infrastructure devices and services based on them. Small towns are also points of accumulation of cultural and historical landscape components. A different but important role is played by small towns located in metropolitan areas. They have developed functions complementary to the dominant city, e.g. "bedroom", logistics or commercial. When characterizing the significance of Polish small towns, it cannot be ignored that they are home to almost five million inhabitants.

From the beginning of the Polish system transformation, however, most of these localities have experienced structural development problems and are in a state of regression or stagnation. This is manifested by the decrease in population, unemployment, decapitalization of residential, production, technical and social infrastructure, disorder of space, migration of enterprises and their capital, increase in crime, alcoholism and other pathologies, the reduction of residents' income as well as the availability and quality of services, degradation of monuments and other negative phenomena. Much attention has been paid to these processes in literature, and their complex is referred to as the shrinking of small towns. Therefore the local authorities often have numerous and specific expectations towards the state's local development policy. The author encountered this situation many times in cooperation with the authorities of 13 such towns in 2000-2018 during the construction and implementation of their development strategies.

In socio-economic terms, a small town is usually perceived as a spatially coherent, but diversified, relationship between the local community and the local economy, having specific socio-cultural, spatial, infrastructural and economic characteristics, clearly differentiating it from rural towns and similar medium-sized associations, and even more so than in urban areas. The methods used to determine which towns belong to this class, however, are varied. In the conducted research it was assumed that these are places whose population ranges from 5 to 20 thousand residents. Therefore, the research population was created by the local authorities of all Polish towns that are urban communes or urban parts of urban-rural communes that meet the presented criterion. Its number of 368 units was determined as of 31 December 2018 using the GUS Local Data Bank; 50 authorities were drawn from this group, which is $13.6 \%$ of all of them.

Their executive bodies, i.e. the mayors, were recognized as the best source of information about the expectations of the surveyed authorities. Of all the players making up local authorities, they have the greatest individual impact on local policy of local development and have the richest knowledge about its results. To obtain information from the mayors, the diagnostic survey method was chosen. As a survey technique, a long personal interview based on a standardized scenario was chosen, the main part of which was essentially, but not completely structured, questions. Interviews were conducted from 11-28 February 2019 as part of a continuing research individual program. 


\section{Identified expectations towards Polish state policy of local development}

The first, most often expressed by the mayors' ( $81 \%$ of responses) expectation in relation to the state policy of local development, is to stop the activities interpreted by them as aimed at the partial limitation of local self-government. According to the respondents, such activities were introduced in the last few years, e.g. establishing supervision over water prices, limiting the freedom to shape school networks and choosing their management, prohibiting the employment of executive bodies' (i.e. mayors') assistants and advisors, introducing a limit of the two terms for mayors and reducing their salary by $20 \%$. These activities also included carrying out reforms of primary education in a manner contrary to the opinion of most local governments, as well as the lack of compensation for the decline in budget revenues, which resulted in an increase in the PIT-free amount. The respondents are afraid of further, similar changes in local government law, including even the introduction of assessments of the advisability of local government activities by the government administration. The first attempt in this regard ended in the President's veto, but the Ministry of the Interior and Administration has announced a return to this project. Therefore, dominant among the identified expectations towards the state's local development policy is not some expectation referring to its details or even areas, but the expectation of its premise and systemic foundations.

The second identified expectation refers to one of the discussed policy areas, namely the expectation of changes in the distribution of aid funds to local governments, especially those coming from EU funds (69\% of responses). Within this general expectation, specific expectations can be distinguished. Firstly, the respondents expect an increase in the subjectivity of local governments in applying for these funds and in their spending (51\% of responses). In their view, the current distribution systems for these funds often push LD goals set at state level, while locally set goals remain with insufficient funding sources. Secondly, the respondents expect the distribution systems of the discussed funds to be improved ( $47 \%$ of responses). The need to increase the transparency of the application selection processes and reduce the number of stages of their evaluation was emphasized. The need to remove unnecessary, supervisory and repressive functions of these systems, introduce better appeal mechanisms, reduce bureaucracy and exclude "changing rules during the game" was also pointed out. It is also expected to expand training support in the preparation of projects to be co-financed (43\% of responses). However, the respondents are not concerned with formal and legal issues, but with economic, social, environmental, management and other knowledge related to the given support program and taking into account the specificity of small towns. The need to extend the possibilities of obtaining aid funds by combining this process with public-private partnerships was also pointed out ( $12 \%$ of responses). This possibility would reduce the risk of failure in the implementation of the most difficult development projects, consisting in failure to achieve the expected social, economic or environmental effects. 
The third general expectation of small town authorities towards state local development policy also concerns finances. However, the author decided to separate them from those discussed above because they are not related to incidental, supplementary financing, but to the permanent and basic one. This expectation is a multidimensional reform of the self-government financing system $(67 \%$ of responses). First of all, mayors expect a real increase in the income of municipalities, so as not only to be able to carry out mandatory tasks, but also optional tasks to the extent corresponding to the needs, aspirations and capabilities of local communities $(60 \%)$. Among the listed elements was the standardization of obligatory, municipal public services and then its connection with the amounts of subsidies (55\%). Today, it often happens that tasks that are supposed to be financed by the state, are in fact financed by municipalities from their own resources, which limits the possibility of implementing optional tasks. In this respect, the necessity to standardize educational services was most frequently mentioned (43\%). The expected reform would also include the introduction of a cadastral tax on real estate used for business purposes (29\%), a change in the status of shares in state taxes PIT and CIT for own income. The need to limit the limitation of municipal debt (26\%) was also emphasized, which unnecessarily limits not only taking loans and issuing bonds, but also obtaining aid funds, due to difficulties in financing their own contribution. Mayors from towns within or around which, by decision of supralocal authorities, legal forms of nature and landscape protection were established (e.g. Natura 2000), indicated that their self-governments should receive permanent financial compensation from the state budget (17\%). They argued that these protection measures mainly serve supralocal interests and restrict $\mathrm{LD}$, which should be compensated.

The fourth group of identified expectations are expectations for improvement or extension of the municipal instruments to stimulate $\mathrm{LD}$ ( $59 \%$ of responses). First of all, small town authorities (24\%) would like to be able to apply concessions and exemptions in these PIT and CIT taxes (after their shares in them are exchanged for own income), as well as to be able to grant specific subsidies to private entities. This expectation is argued by the desire to stimulate external investments, stop the migration of local companies, and the supralocal valorisation of unique local products. Investment is also to be gained through expanding access to international promotion channels created and managed by the state $(21 \%)$. Access to these channels is also to facilitate the acquisition of tourists, patients, external organizers of supralocal events (in fields of culture, entertainment, sport, recreation etc.) and even new residents. Secondly, the need to limit the protection of agricultural land against urbanization by transferring partial competences to communes to "de-agriculture" was pointed out $(17 \%)$. Agricultural lands within city limits are often not tilled for many years, but they cannot be paved over because they have agricultural status. Equipping municipalities with the right to change this status would increase their possibilities, e.g. to obtain external investments. Real estate is also affected by another, often raised expectation $(15 \%)$, to increase the possibility of take-over or the preferential acquisition of real 
estate owned by state entities (e.g. National Support Centre for Agriculture, Military Property Agency), permanently unused, degraded and not covered by plans for use (e.g. post-industrial, post-military) for municipalities that have investment intentions against them. It is also desirable by some mayors (7\%) to allow municipalities to use some components of private property for a fee, without the consent of their owners, for the development of supralocal tourist and recreational functions (e.g. snow law, trail law). The authorities of small towns located in the vicinity of large cities would also like to be able to differentiate the fees for municipal services depending on whether their recipients are registered in the commune or not $(5 \%)$.

The remaining, identified expectations of local authorities are characterized by their large diversity, and therefore have been combined into a aggregated group of other expectations. The necessity to create pay mechanisms encouraging the selfgovernment career of the highest qualified public managers was often pointed out (24\%). It was emphasized that leaving the best of them to business does not serve the state at all. It was also emphasized that the cutting of mayors' remuneration recently carried out by the state authorities was a harmful step taken in the opposite direction. In several cases $(3 \%)$ the need to implement state programs increasing the capacity of small towns to absorb innovations, knowledge and capital created in large cities and to redistribute them to rural areas was signalled. However, the surveyed mayors could not determine which such programs could be prepared and executed. It was also pointed out the need to increase the responsibility of councillors for managing LD (4\%), and in the case of an executive body it was suggested to professionalize it, i.e. abandon the election of the mayor by the inhabitants, for the employment by the council (3\%). Both of these changes are to contribute to the professionalization of LD management through increased involvement and the accumulation of knowledge in decisive and executive bodies of local governments. Expectations also included a forced combination of urban communes containing small towns and surrounding rural communes $(2 \%)$. Both these self-government structures usually constitute in fact one local system, but managed by two different local authorities, which makes managing their development difficult. It was also postulated to remove contradictions and ambiguities of local government law, which limit municipal possibilities to stimulate LD and increase the risk of this activity (3\%). The last of the indications concerned the improvement of supralocal governance patterns (3\%). According to the respondents, they contain too much aggressive cross-party competition, and even nepotism and existence of coteries, which is often replicated at the level of local authorities and reduces the effectiveness of LD management.

\section{Conclusions}

Among the identified expectations of small town authorities towards the state policy of local development, the expectation of maintaining strong local self-governance dominates. This is associated with fears of transforming local governments from 
active, creative and significantly independent co-creators of development policy into the passive tools of such a policy of state authorities. Despite the signals of centralization, such fears do not seem to be fully justified. Nevertheless, they indicate the need for the state government to dispel doubts in this respect. The identified expectations also indicate that the authorities of small towns want not only to maintain self-governance, but also to further its development. This is how one should interpret the numerous, identified expectations towards the reform of local government finances, changes in the distribution systems of aid funds, new instruments to support $\mathrm{LD}$, new rights to a deeper adaptation of operating methods to local conditions and a number of other changes. These expectations show that the surveyed authorities recognize that contemporary socio-economic development is based on repeatedly new factors and dependencies, and stimulating its components, e.g. entrepreneurship, creativity, innovation, human and social capital, etc., requires constantly new competence, resources, knowledge, information and responsibility. It is also testimony that the authorities of small towns expect not only to maintain, but also to increase trust in their self-governments and self-governance in general, mainly through the decentralization of socio-economic development policy based on compromises between central and local authorities.

As stated by one of the fathers of the local government reform in 1990, J. Regulski, its basis was "the desire to create units capable of conducting independent urban and communal development policy" (Regulski, 2008, p. 9). These units, i.e. municipalities, fulfilled their role measurably contributing to the development of the country. Therefore, the identified expectations of small town authorities should be treated as another reason for the next stage of this reform (cf. e.g. Bober et al., 2013; Antczak et al., 2013; Dziemianowicz, Peszat, and Przyborowski, 2015) and the public debate preceding it on the contemporary role of local governments in the development of the state. It should, however, be a debate that deeply engages the final beneficiaries of local development policies, i.e. society, not just representatives of the government, self-governments and experts. A model can be the similar debate carried out several years ago in Great Britain (see e.g. Storey, and Farrar, 2009). Without such debates and reforms, one of the most important engines driving our economy, self-government, will gradually lose its driving force.

\section{Bibliography}

Antczak, R., Dąmbska, A., Glusman, J., Herbst, K., Kryczka, A., and Trzyna, S., (2013). Samorząd 3.0. Raport Forum Od-nowa. A. Dąmbska, S. Trzyna (Eds.). Forum Od-nowa, Warszawa.

Bober, J., Hausner, J., Izdebski, H., Lachiewicz, W., Mazur, S., Nelicki, A., Nowotarski, B., Puzyna, W., Surówka, K., Zachariasz, I., and Zawicki, M., (2013). Narastające dysfunkcje, zasadnicze dylematy, konieczne działania. Raport o stanie samorzadności terytorialnej w Polsce. Kraków: Uniwersytet Ekonomiczny w Krakowie, Małopolska Szkoła Administracji Publicznej. 
Dziemianowicz, W., Peszat, K., and Przyborowski, K. (2015). Natura 2000 w kontekście konkurencyjności i możliwości rozwojowych gmin w Polsce. Studia Regionalne i Lokalne, 1(59), 86-103.

Governa, F., and Salone, C. (2004). Territories in action, territories for action: The territorial dimension of Italian local development policies. International Journal of Urban and Regional Research, 28(4), 796-818.

Malik, K. (2012). Konteksty oceny efektywności polityki rozwoju regionu. Prace Naukowe Uniwersytetu Ekonomicznego w Katowicach, 149-158.

Ofiarska. M., and Ofiarski. Z. (2008). Istota rozwoju lokalnego i źródła jego finansowania ze szczególnym uwzględnieniem Funduszu Rozwoju Inwestycji Komunalnych. In Wspótpraca dla rozwoju. Samorzą terytorialny jako reżyser lokalnego rozwoju. Polityka społeczna jako instrument rozwoju (s. 68-81). Szczecin: Wyższa Szkoła Administracji Publicznej w Szczecinie, Wyższa Szkoła Pedagogiczna TWP w Warszawie.

Pająk, K. (2007). Samorząd terytorialny w kształtowaniu rozwoju lokalnego. Studium politologiczne. Piła: Państwowa Szkoła Zawodowa im. Stanisława Staszica w Pile.

Pietrzyk, I. (1995). Paradygmat rozwoju terytorialnego. In W. Kosiedowski (Ed.). Gospodarka przestrzenna i regionalna $w$ trakcie przemian (s. 10-21). Toruń: Uniwersytet Mikołaja Kopernika,

Pietrzyk, I. (2001). Paradygmat rozwoju terytorialnego. In W. Kosiedowski (Ed.). Gospodarka i polityka regionalna okresu transformacji (s. 55-66). Toruń: Uniwersytet Mikołaja Kopernika w Toruniu.

Regulski, J., (2008), Sterowanie rozwojem. Próba ujęcia teoretycznego. In Wspótpraca dla rozwoju. Samorzad terytorialny jako reżyser lokalnego rozwoju. Polityka społeczna jako instrument rozwo$j u$ (s. 9-20). Szczecin: Wyższa Szkoła Administracji Publicznej w Szczecinie.

Rogers, V. (2006). Reforming regional and local development policy in france. land use policy, (23), 302-310.

Storey, V. A., and Farrar M. (2009). The new localism in the UK: Local governance amid national goals. Yearbook of the National Society for the Study of Education, 108(1), 1-20.

Wojtasiewicz, L. (1990). Planowanie rozwoju lokalnego. In B. Gruchman, J. Tarajkowski (Eds.). Rozwój gospodarki lokalnej w teorii i praktyce (s. 37-47). Warszawa: Uniwersytet Warszawski. 